\title{
Technological Innovation and Management Skills: Case Study of the Museo Archeologico di Napoli
}

\author{
Filomena Izzo ${ }^{1}$ \\ ${ }^{1}$ University of Campania "Luigi Vanvitelli", Italy \\ Correspondence: Filomena Izzo, University of Campania "Luigi Vanvitelli", Italy. \\ Received: May 26, 2017 \\ Accepted: July 3, $2017 \quad$ Online Published: July 4, 2017 \\ doi:10.5539/ibr.v10n8p44 \\ URL: https://doi.org/10.5539/ibr.v10n8p44
}

\begin{abstract}
The aim of this article is to contribute to the debate on how management positions in museums can contribute in successfully implementing technological innovations within a museum. The results of a case study on the Museo Archeologico Nazionale di Napoli (MANN) - which covers the theme of transferrable skills of a museum director for the successful implementation of technological innovations to improve the service the museum offers to the benefit of the public.
\end{abstract}

Keywords: technological innovation, management skills, museums

\section{Introduction}

Starting from the nineties the museum sector has seen numerous changes that have made it considerably more complex. Think of the reduction in public financing that has forced museums to deal with the logic of the market or, better yet, the increase in competition due to alternative cultural programs.

In recent years, museums have tried to find new ways to provide a unique experience for tourists by implementing technological innovations to enhance their visits (Izzo, Mustilli, \& Guida, 2015; Izzo, Mustilli, Sasso, \& Solima 2016; Solima, Della Peruta, \& Del Giudice, 2015; Yovcheva, Buhalis, \& Gatzidis, 2013). A recent survey on strategies implemented in major museums worldwide with regard to the digitization process, the use of these instruments and the reassessment of websites carried out by Axiell in 2016 for the Museums and the Web Conference shows that the use of integrated ICT applications had a significant impact on the public: $48 \%$ of the museums saw an increase in physical visits, $50 \%$ saw an increase in the number of visits to their websites, and $82.3 \%$ of the museums recorded an increase of social media visitors. Museums could increase their competitive advantage over their direct competitors by improving the quality of the visit experience. Moreover, this choice can be of strategic importance with respect to reputation in order to improve museum attractiveness and, more generally, its ability to relate to its stakeholders. Obviously, a satisfied visitor will share his or her experience with other users, thereby increasing the visibility of the museum and its 'social' rating, just as a dissatisfied visitor might. Additionally, a content visitor is more likely to establish a long-lasting relationship with the museum beyond the visit through a digital connection. In other words, the museum can activate loyalty with its audience - a prerequisite for the development of the museum's marketing strategy. The importance of digital communication for cultural institutions is clear, but what are the factors that can contribute in successfully implementing technological innovations within a museum?

Most research assesses the determinants that lead to the choice of adopting In-formation Technology (IT) to include the factors that influence acceptance and use of such a system (Fuller, 1996; Thong, 1999; Bharadwaj \& Soni, 2007; Irvine \& Anderson, 2008). Other research focuses its attention on the company structure, or rather, whether the organization is ready and willing to accept the technological innovation (Davis, 1989; Tomatzky \& Fleischer, 1990; Rogers, 1995; Oliveira \& Martins, 2011; Cranmer, Jung, tom Dieck, \& Miller, 2016; Jung, Chung, \& Leue, 2015; Izzo, 2017).

Parallel to this process of organizational change, both in academia as with practitioners, more attention is placed on the importance of developing adequate management skills to better respond to the complex challenges in the sector. To achieve greater company performance, individuals in management positions must possess both technical skills linked to the management of complex organizations, as well as a portfolio of emotional, relational and cognitive skills (Hopkins \& Bilimoria, 2008; Nolan, Conway, Farrell, \& Monks, 2010; Wang, 
2013). The skills under exam refer to the capability to efficiently recognize, understand and manage one's own emotions and those of others, and the ability to analyze information and situations (Boyatzis, 2009).

The aim of this article is to contribute to the debate on how management positions in museums can contribute in successfully implementing technological innovations within a museum.

Focus is on a case-study of the Museo Archeologico Nazionale di Napoli (MANN), which analyzes the transferrable skills a museum director should possess for the successful implementation of technological innovations to improve the service that the museum makes available to the public.

We then present the theoretic framework, the project methodology, main project results and a discussion.

\subsection{Theoretic Framework}

Numerous studies show how people constitute the source of an organization's competitive advantage. In other words, how the success of an organization is closely linked to the knowledge, abilities and skills of its human capital (Thompson, 1967; Becker, 1983; Pfeffer, 1994; Huselid, Jackson, \& Schuler, 1997; Youndt, Snell, Dean, \& Lepak, 1996; Castaner, 1997; Cappelli, 1999; Moretti, 1999).

From last few years practitioners and academia related people have evolved considerably with Talent Management literature (Meyers \& Woerkom, 2014; Minbaeva \& Collings, 2013; Nijs, Gallardo-Gallardo, Dries, \& Sels, 2014; Schiemann, 2014; Vaiman \& Collings, 2013) focusing on talented human help to generate superior outputs (Sparrow \& Makram, 2015; Ali, Lei, Ali, \& Hussain, 2017).

In this viewpoint, many studies focused on the correlation between the leader and the de velopment of business through the study of what he does (Verstraete, 1999, Schmitt 2003, Chandler \& Jansen, 1992; Herron \& Robinson, 1993). They demonstrate that the leader influences strongly the development and sustainability of the company by his personal traits but also by mobilizing his skills in the exercise of his functions. Moreover, Bayad, Arcand, and Arcand (2002), and Loué and Baronet (2008) verified that the leader skills are the best predictors of firms performance. In the same way, other researches on skills of the leader, point out that leader skills are more directly related to the performance of companies (Lorrain, Belley, \& Dussault, 1998; Gartner, 1988). More in detail management skills, leader skills and entrepreneurial skills seem to be an important factor in the success of any business (Bayad et al., 2002; Jaoua \& Radouche, 2014).

Then it is well-known that the leader skills prove predictors of performance (Bayad et al., 2002), and the performance differences between firms are due to the different skills of heads of business. Specifically, technical, managerial and entrepreneurial corporate chef is an important factor in the future success of the company (Lorrain et al., 1998).

Beginning with the assumption that individuals in the upper echelons in small businesses make decisions and executes orders that influence the entire organization, directly impacting the business' outcome (Sadler-Smith, Hampson, Chaston, \& Badger, 2003; Gerli, Tognazzo, \& Gubitta, 2014). In analyzing the case study the goal was to contribute to the ongoing discussion on the skills required by museums, investigating which transferrable skills individuals in management positions must have.

\section{Method}

The museum director is a fundamental position as it not only is responsible for the business' financial management but also represents the museum when interfacing with the various stakeholders (Bagdadli \& Paolino, 2006; Montanari \& Paolino, 2011). To answer the research question on identifying the transferrable skills of a museum manager, the research analyzed the skills of the director (Paolo Giulierini) of the Museo Archeologico Nazionale di Napoli at the time in reference (2015-2017).

Data on the skills were gathered using the Behavioral Event Interview (BEI) (Boyatzis, 1998; McClelland, 1998) approach, which represents an evolution of the Critical Incident Interview (Flanagan, 1954) technique. This enables the gathering of information on specific episodes where the interviewee felt to be particularly efficient or inefficient. This type of interview, like storytelling, (Boje, 1991), is a way to overcome the limits that are generally associated with techniques of self-evaluation regarding social and emotional skills and, in general, emotional intelligence tests (Boyatzis, 2009; Ryan, Emmerling, \& Spencer, 2009).

The interview, which lasted about two hours, concerned the description of events that took place in the last year where the interviewee felt to be particularly efficient or inefficient. The analysis focused on the emotional, social and cognitive skills (Boyatzis, 1982; Boyatzis, Goleman, \& Rhee, 2000; Boyatzis, Gask, \& Wei, 2014; Gerli \& Bonesso, 2011; Puccio, Mance, \& Murdock, 2011; Dyer, Gregersen, \& Christensen, 2008; Scapolan, Montanari, Bonesso, \& Gerli, 2016). The following were analyzed: 
- Thirteen Emotional Skills

1. self-awareness

2. observation

3. experimentation/exploration

4. optimism

5. eye for detail

6. source of change

7. efficiency minded

8. drive

9. planning

10. self-control

11. flexible

12. goal oriented

13. emotional awareness

- Eleven Social Skills

1. involving others

2. interpersonal networking

3. verbal communication

4. ability to manage conflict

5. service oriented

6. organizational skills

7. leadership

8. team capabilities

9. developing others

10. persuasion

11. empathy

- Seven Cognitive Skills

1. vision

2. strategy oriented

3. team building

4. quantitative analysis

5. concept oriented

6. aware of methods

7. systemic mindset

The museum director has skills that have been encoded, starting with the story of different behavior on the part of the interviewee and, therefore, can be the list of skills the museum manager activates to execute a task. The interviewee focused on experience in planning, organization and implementation of a series of technological innovations for the benefit of the public.

\section{Results}

The MANN is among the oldest and most important museums in the world in wealth and uniqueness of its holdings and for its contribution to the European cultural outlook. The Museum's goal is to de velop and spread the knowledge of the history and culture of the people through the conservation, study, interpretation and appreciation of its exceptional collections. For this purpose, it addresses visitors of all ages, income, education and background, planning the experience of innovative access and approach that stimulate the understanding of 
the roots of the population.

The Museum (that covers an area of approx. 18,500 sq.m) is not only a museum site, it has a Restoration Laboratory, a Library and the Historical Archives that represent, for their scientific contribution, works of excellence on an international scale.

The MANN is the first of the twenty independent state museums established thanks to the "Riforma Franceschini", equipped with a long-term plan to identify its strategic goals for 2016-2019. The new director of the Museum, Paolo Giulierini, nominated on October 1, 2015 and in office until September 30, 2019, decided to take this path (the implementation of the Strategic Plan) and was very brave as none of the independent museums is obligated to produce and, even less, publicly share the document.

The Strategic Plan illustrates ex-ante the museum Director's strategies and choices, determining the supporters' responsibilities. Furthermore, since it has been made public (i.e., made available to download in pdf from the museum's website), the monitoring of the Director's work is not limited to the "political/administrative" arena, but takes-on the connotation of real and true social control - every citizen will be able to ask the Director on a public platform for any clarification of any shortcomings of the Strategic Plan.

The Director is fully aware of the role of contemporary society with its access to knowledge in digital format, reason why he has provided for the implementation of a digital strategy to enhance the visitors' experience. The Director identified some objectives specified as follows:

1. By 2016 - trial of an Augmented Reality app of the model of Pompei (http://www.museoarcheologiconapoli.it/en/mann-app/)

2. By 2017 - re-design of the website and presence on Social Media. The new website will be the center for spreading the digital contents of the museum which will be conveyed and shared through Social Media (Facebook, YouTube, Twitter, Instagram, Pinterest, etc.).

3. By 2017 - production of the video game "Father and Son" (http://www.fatherandsongame.com/) for audience development

4. By 2019 - launching of a digital campaign of the Museum's permanent collections, both in 2D and 3D. Will be achieved also thanks to eventual support from external organizations such as Goggle Art Institute and Apple, to improve the digital accessibility of the most important exhibits of the MANN. The outcome of the digital campaign will be progressively spread through its website and other chosen channels.

The work teams in charge of the planning, organization and implementation of the various technological solutions were formed by the museum director, the internal staff and external experts. The museum director was involved in all the development phases of the various technological solutions implemented to date, as was the museum staff in the projects.

Achievement of the specific goals of the Strategic Plan was made possible thanks to the determination of Director Giulierini, who personally monitored all the activities, showing great intellectual curiosity and as much determination to reach the goals defined in the design phase. The courage to adopt such a well-structured digital strategy in such a short time is to be noted; a unique experience on the national level.

Another interesting outcome was the involvement of the museum staff that showed great pride and sense of belonging to its own cultural institution, gaining a more dynamic, innovative and open image. This pride has reinforced the staff's commitment which has transferred over to the willingness to fully contribute in the various projects.

The director's interview produced two major results. The first relates to emotional, social and cognitive skills . Particularly important were the understanding and the managing others (persuasion, empathy and involving others) and the emotional skills which are performance anxiety, drive and planning. Highlighting, therefore, that it is mostly the social (i.e., relationships) and emotional skills that characterize the role of a museum director. Less important are the results of the cognitive skills which are team building and quantitative analysis.

Other skills that characterize the manager under exam are: goal oriented (referring to achieving standards of excellence), self-control (referring to the ability to control one's own emotions in stressful situations and to show optimism) and source of change (referring to the ability to promote change within the organization). Highlighting, therefore, that the manager, in carrying-out his/her own work, resolves to continually reach goals of excellence and calmly perseveres in pursuing them, facing situations that could hinder achieving the goals.

A second group of distinctive management skills under exam for the successful implementation of technological innovations within the museum concerns the social or relational skills pertaining to managing others and, in 
particular, the development of others and leadership.

The skill, development of others, refers to the ability to promote learning and long-term development of collaborators, playing the role of coach and mentor. Examples of behavior associated to this skill are giving feedback on work done to maintain and/or improve performance, supplying information, tools and other resources useful for carrying-out duties or for improving abilities, or clearly expressing goals to be reached giving encouragement and support (Boyatzis, 1982; Boyatzis, Gask, Wei, 2014).

Leadership, instead, concerns the ability to become the guide of a group. Leaders know exactly what their role is in a team, they know how to interpret situations and are able to create a positive work environment.

The interesting aspect concerns the fact that, according to the model of skills that inspired this research, leadership does not derive from the hierarchical position held, rather, it is a combination of the behavior activated by the person regardless of their official role within the organization. Notably, leaders are such because they conduct engaging activities or projects, inspire others by sharing a vision or assigning goals, and they know how to build-up pride and team spirit. Successful managers posses emotional intelligence, since in critical situations they are aware of their own strengths and weaknesses and know how to understand their own emotions.

\section{Discussion}

The research carried-out has supplied a dual contribution. First of all, it highlights the centrality obtained from the transferrable skills in management positions in the museum sector. Secondly, it contributed in identifying the "distinctive skills" that distinguish the manager of a museum in the successful implementation of a technological innovation in a museum.

In the context under exam, it can be concluded that, to successfully implement a technological innovation, museum management must possess the ability to lead their own collaborators by activating an "inspiring" leadership. That is, a long-term leadership that "motivates" and does not simply "push" the organization. In other words, it regards managers that identify long-term goals for their museum and contemporaneously propose opportunities for development, giving the possibility for growth and promotion.

Highlighted in the results is the importance of the skill of involving others (refer-ring to the ability to involve individuals), whether belonging to the business context or external to the museum business, in reaching individual goals.

The set of skills determined in this research (vision, developing others and leadership, source of change, self-control, goal oriented) show a strong internal cohesion. For example, the ability to lead collaborators, instilling a sense of pride for the organization expressed through leadership skills, is coherent with the cognitive capacity to know how to represent and share the museum's future goals. Having the skill to motivate themselves to introduce innovations and having the capacity to support the growth of their collaborators so that they possess the necessary skills to efficiently carry-out their duties.

The main limit of the research is linked to its exploratory character. The results, in fact, cannot be generalized as the study is based on only one case study. However, it opens prospective future research to be conducted with a greater number of museum managers to be interviewed, but also addressing managers in different cultural sectors.

\section{References}

Ali, M., Lei, S., Ali, S. A, \& Hussain, S. T. (2017). Relationship of External Knowledge Management and Performance of Chinese Manufacturing Firms: The Mediating Role of Talent Management. International Business Research, 10(6), 248-258. https://doi.org/10.5539/ibr.v10n6p248

Bagdadli, S., \& Paolino, C. (2006). Institutional Change in Italian Museums: Does the Museum Director Have a Role to play? International Journal of Arts Management, 8(3), 4-18.

Bayad, M., Arcand, M., \& Arcand, G. (2002). Le regroupement stratégique des pratiques mobilisatrices de gestion des ressources humaines. Gestion, 2, 121-137.

Becker, G. (1983). Human Capital. Chicago: University of Chicago Press.

Belley, A., \& Dussault, L. (1998). Les compétences des entrepreneurs: élaboration et validation d'un questionnaire (QCE). Nancy-Metz: CIFEPME.

Bharadwaj, P., \& Soni, R. (2007). E-Commerce Usage and Perception of E-Commerce Issues among Small Firms: Results and Implications from an Empirical Study. Journal of Small Business Management, 45(4), 
501-521. https://doi.org/10.1111/j.1540-627X.2007.00225.x

Boje, D. M. (1991). The storytelling organization: a study of story performance in an office supply firm. Administrative Science Quarterly, 36, 106-126. https://doi.org/10.2307/2393432

Boyatzis, R. E. (1982). The competent manager: a model for effective performance. New York: Wiley Interscience.

Boyatzis, R. E. (1998). Transforming qualitative information. Thousand Oaks: Sage Publications.

Boyatzis, R. E. (2009). Competencies as a behavioural approach to emotional intelligence. Journal of Management Development, 28(9), 749-770. https://doi.org/10.1108/02621710910987647

Boyatzis, R. E., Gask, J., \& Wei, H. (2014). Emotional and social intelligence and Behavior. In (eds.) Princiotta D., Goldstein S., Naglieri J., Handbook of Intelligence: Evolutionary, Theory, Historical Perspective, and Current Concepts. NY: Spring Press New York.

Boyatzis, R. E., Goleman, D., \& Rhee, K. (2000). Clustering competence in emotional intelligence: Insights from the Emotional Competence Inventory (ECI)s. In (eds.) Barr-On R. \& Parker J.D.A., Handbook of emotional intelligence. San Francisco: Jossey-Bass.

Cappelli, P. (1999). The new deal at work: Managing the market driven workforce. Boston: Harvard Business School Press.

Castaner, X. (1997). The tension between artistic leaders and management in arts organisations: The case of Barcelona Synphony Orchestra. In (eds.) Fitzgibbon, M. \& Kelly, A., From Maestro to Manager: Critical Issues in Arts and Cultural Management. Dublin: Oak Tree Press.

Chandler, G. N., \& Jansen, E. (1992). The founder's self-assessed competence and venture Performance. Journal of Business Venturing, 7, 223-236. https://doi.org/10.1016/0883-9026(92)90028-P

Cranmer, E., Jung, T., Tom, D. M. C., \& Miller, A. (2016). Understanding the Acceptance of Augmented Reality at an Organisational Level: The Case of Geevor Tin Mine Museum. In Information and Communication Technologies in Tourism. Springer International Publishing. https://doi.org/10.1007/978-3-319-28231-2_46

Davis, F. (1989). Perceived usefulness, perceived ease of use, and user acceptance of information technology. MIS quarterly, 13(3), 319-340. https://doi.org/10.2307/249008

Dyer, J. H., Gregersen, H. B., \& Christensen, C. (2008). Entrepreneur behaviours, opportunity recognition, and the origins of innovative ventures. Strategic Entrepreneurship Journal, 2(4), 317-338. https://doi.org/10.1002/sej.59

Flanagan, J. C. (1954). The critical incident technique. Psychological Bulletin, 51(4), 327-358. https://doi.org/10.1037/h0061470

Fuller, T. (1996). Fulfilling IT needs in small businesses; a recursive learning model. International Small Business Journal, 14(4), 25-44. https://doi.org/10.1177/0266242696144002

Gartner, W. B. (1988). Who is an Entrepreneur? Is the Wrong Question. American Journal of Small Business. 12(4), 11-32.

Gerli, F., \& Bonesso, S. (2011). The role of Emotional Intelligence on Innovation: the Case of the Italian Luxury Footwear District. Proceedings of 3rd International Congress of Emotional Intelligence Conference. Rijeka: Faculty of Humanities and Social Sciences, University of Rijeka.

Gerli, F., Tognazzo, A., \& Gubitta, P. (2014). What makes Italian SME entrepreneurs successful? The leverage effect of relational competencies. Piccola impresa, 3, 71-97.

Herron, L. A., \& Robinson, R. B. (1993). A structural model of the effects of entrepreneurial characteristics on venture performance. Journal of Business Venturing, 8, 281-294. https://doi.org/10.1016/0883-9026(93)90032-Z

Hopkins, M. M., \& Bilimoria, D. (2008). Social and emotional competencies predicting success for male and female executives. Journal of Management Development, 12(1), 13-35. https://doi.org/10.1108/02621710810840749

Huselid, M., Jackson, S., \& Schuler, R. (1997). Technical and strategic human resource management effectiveness as determinants of firm performance. Academy of Management Journal, 40(1), 171-188. https://doi.org/10.2307/257025 
Irvine, W., \& Anderson, A. (2008). ICT peripherally and smaller hospitality businesses in Scotland. International Journal of Entrepreneurial Behaviour \& Research, 14(4), 200-218. https://doi.org/10.1108/13552550810887381

Izzo, F., Mustilli, M., \& Guida, M. (2015). Realtà aumentata e valorizzazione dei beni culturali. Riflessioni sull'offerta culturale casertana. Proceedings of Sinergie Annual Conference (797-809). Termoli, Italy: Economics Department, University of Molise.

Izzo, F., Mustilli, M., Sasso, P., \& Solima, L. (2016). Service orientation and technology innovation in museum: Museo Archeologico Nazionale of Naples case study. Proceedings of 26th Annual RESER Conference. Naples-Italy: Economics Department: Federico II University.

Jaoua, F., \& Radouche, T. (2014). The Moderating Role of Leader Skills on the Relationship between Strategic Management and Global Performance: An Empirical Study. International Business Research, 7(8), 59-72. https://doi.org/10.5539/ibr.v7n8p59

Jung, T., Chung, N., \& Leue, M. (2015). The determinants of recommendations to use augmented reality technologies: The case of a Korean theme park. Tourism Management, 49(1), 75-86. https://doi.org/10.1016/j.tourman.2015.02.013

Loué, C., \& Baronet, J. (2010). Entrepreneur's skills, qualitative and quantitative validation of a model of entrepreneurial comptetence. Proceedings of Babson College Entrepreneurship Conference, LausanneSuisse.

McClelland, D. C. (1998). Identifying competencies with behavioural event interviews. Psychological Science, 9(5), 331- 339. https://doi.org/10.1111/1467-9280.00065

Meyers, M. C., \& van Woerkom, M. (2014). The influence of underlying philosophies on talent management: Theory implications for practice and research agenda. Journal of World Business, 49, 192-203. https://doi.org/10.1016/j.jwb.2013.11.003

Minbaeva, D., \& Collings, D. G. (2013). Seven myths of global talent management. The International Journal of Human Resource Management, 24, 1762-1776. https://doi.org/10.1080/09585192.2013.777539

Montanari, F., \& Paolino, C. (2011). Le problematiche organizzative nelle istituzioni culturali. In Carù A., Salvemini S., Management delle istituzioni artistiche e culturali. Milano: Egea.

Moretti, A. (1999). Un'organizzazione museale multiunit: i Musei Civici di Venezia. In Zan L., Conservazione e innovazione nei musei italiani: management e processi di cambiamento. Milano, Etas.

Nijs, S., Gallardo-Gallardo, E., Dries, N., \& Sels, L. (2014). A multidisciplinary review of the definition, operationalization, and measurement of talent. Journal of World Business, 49, 180-191. https://doi.org/10.1016/j.jwb.2013.11.002

Nolan, C., Conway, E., Farrell, T., \& Monks, K. (2010). Competency needs in Irish hotels: Employer and graduate perspectives. Journal of European Industrial Training, 34(5), $432-454$. https://doi.org/10.1108/03090591011049800

Oliveira, T., \& Martins, M. (2011). Literature review of information technology adoption models at firm level. The Electronic Journal Information Systems Evaluation, 14(1), 110-121.

Pfeffer, J. (1994). Competitive Advantage through People. Boston: Harvard Business School.

Puccio, G. J., Mance, M., \& Murdock, M. C. (2011). Creative Leadership. Skills that drive change. New York: Sage.

Rogers, E. (1995). Diffusion of innovations. New York: Everett.

Ryan, G., Emmerling, R. J., \& Spencer, L. M. (2009). Distinguishing high performing European executives: the role of emotional, social and cognitive competencies. Journal of Management Development, 28(9), 859-875. https://doi.org/10.1108/02621710910987692

Sadler-Smith, E., Hampson, Y., Chaston, I., \& Badger, B. (2003). Managerial behaviour, entrepreneurial style, and small firm performance. Journal of Small Business Management, 41(1), 47-67. https://doi.org/10.1111/1540-627X.00066

Scapolan, A., Montanari, F., Bonesso, S., \& Gerli, F. (2016). Le competenze manageriali nelle performing arts. In Taormina, A., La formazione al management culturale. Milano: Franco Angeli.

Schiemann, W. A. (2014). From talent management to talent optimization. Journal of World Business, 49(2), 
281-288. https://doi.org/10.1016/j.jwb.2013.11.012

Schmitt, C. (2003). La science allemande du droit dans sa lutte contre l'esprit juif. Cités, 14, 173-180. https://doi.org/10.3917/cite.014.0173

Solima, L., Della Peruta, M. R., \& Del Giudice, M. (2015). Object-Generated Content and Knowledge Sharing: the Forthcoming Impact of the Internet of Things. Journal of the Knowledge Economy, 7(3), 738-752. https://doi.org/10.1007/s13132-015-0243-x

Sparrow, P., \& Makram, H. (2015). What is the value of talent management? Building value -driven processes within a talent management architecture? Human Resource Management Review, 25(3), 249-263. https://doi.org/10.1016/j.hrmr.2015.04.002

Thompson, J. (1967). Organizations in Action. New York: McGraw-hill.

Thong, J. Y. (1999). An integrated model of information systems adoption in small businesses. Journal of Management Information Systems, 15(4), 187-214. https://doi.org/10.1080/07421222.1999.11518227

Tomatzky, L., \& Fleischer, M. (1990). The process of Technology Innovation. Lexington: Lexington Books.

Vaiman, V., \& Collings, D. G. (2013). Talent management: Advancing the field. The International Journal of Human Resource Management, 24(7), 1737-1743. https://doi.org/10.1080/09585192.2013.777544

Verstraete, T. (1999). Entrepreneuriat: connaître l'entrepreneur, comprendre ses actes. Paris: L'Harmattan, Collection Economie et Innovation.

Wang, Y. F. (2013). Constructing career competency model of hospitality industry employees for career success. International Journal of Contemporary Hospitality Management, 25(7), 994-1016. https://doi.org/10.1108/IJCHM-07-2012-0106

Youndt, M., Snell, S., Dean, J., \& Lepak, D. (1996). Human resource management manufacturing strategy and firm performance. Academy of Management Journal, 39(4), 836-866. http://dx.doi.org/10.2307/256714

Yovcheva, Z., Buhalis, D., \& Gatzidis, C. (2013). Engineering Augmented Tourism Experiences. In (eds.) Cantoni L., Xiang Z., Information and Communication Technologies in Tourism. Heidelberg: Springer. https://doi.org/10.1007/978-3-642-36309-2_3

\section{Copyrights}

Copyright for this article is retained by the author(s), with first publication rights granted to the journal.

This is an open-access article distributed under the terms and conditions of the Creative Commons Attribution license (http://creativecommons.org/licenses/by/4.0/). 